DOI 10.35694/YARCX.2019.46.2.019

\title{
К ИСТОРИИ РАЗВИТИЯ ВЕТЕРИНАРНОЙ СЛУЖБЫ ЯРОСЛАВСКОЙ ОБЛАСТИ
}

\section{Т.К. Тимакова}

к.В.н., доцент, доцент кафедры ветеринарно-санитарной экспертизы

Е.М. Горбунова (фото)

обучающаяся технологического факультета

В.И. Дорохова

К.э.н., доцент, начальник управления по научной работе и международному сотрудничеству

ФГБОУ ВО Ярославская ГСХА, г. Ярославль

Государственная ветеринарная служба Ярославской области, как и России в целом, прошла сложный исторический путь развития и в настоящее время является самостоятельной структурой, которая обеспечена высококвалифицированными кадрами и способна решать самые сложные задачи в обеспечении продовольственной безопасности Российской Федерации.

Материалом исследований явились архивные материалы, опубликованные статьи по вопросам ветеринарной деятельности, а также уникальный документ - годовые отчёты 1886-1907 гг. Ярославской губернии [1].

Первые упоминания о ветеринарной службе Ярославской области датируются началом XIX века. В этот период наблюдались массовые вспышки различных заболеваний сельскохозяйственных животных, на борьбу с которыми местные власти приглашали ветеринарных специалистов [2].

Структура ветеринарной службы России начала складываться во второй половине XIX века: 2 декабря 1868 года было организовано Центральное ветеринарное управление при Министерстве внутренних дел с подчинёнными ему губернскими и уездными ветеринарными врачами (рис. 1).

В обязанности ветеринарного управления вменялось:

- изучение мер к лучшему устройству ветеринарной части и принятие мер по предупреждению и прекращению повальных и заразных болезней домашних животных;

- составление наставлений и инструкций по ветеринарии относительно прекращения эпизоотий;

- издание популярных сочинений о правильном содержании и лечении животных;

- испытание новых открытий в практической ветеринарии;

- рассмотрение и дозволение на продажу зоофармацевтических средств;

- обсуждение мер к облегчению прогона скота. 


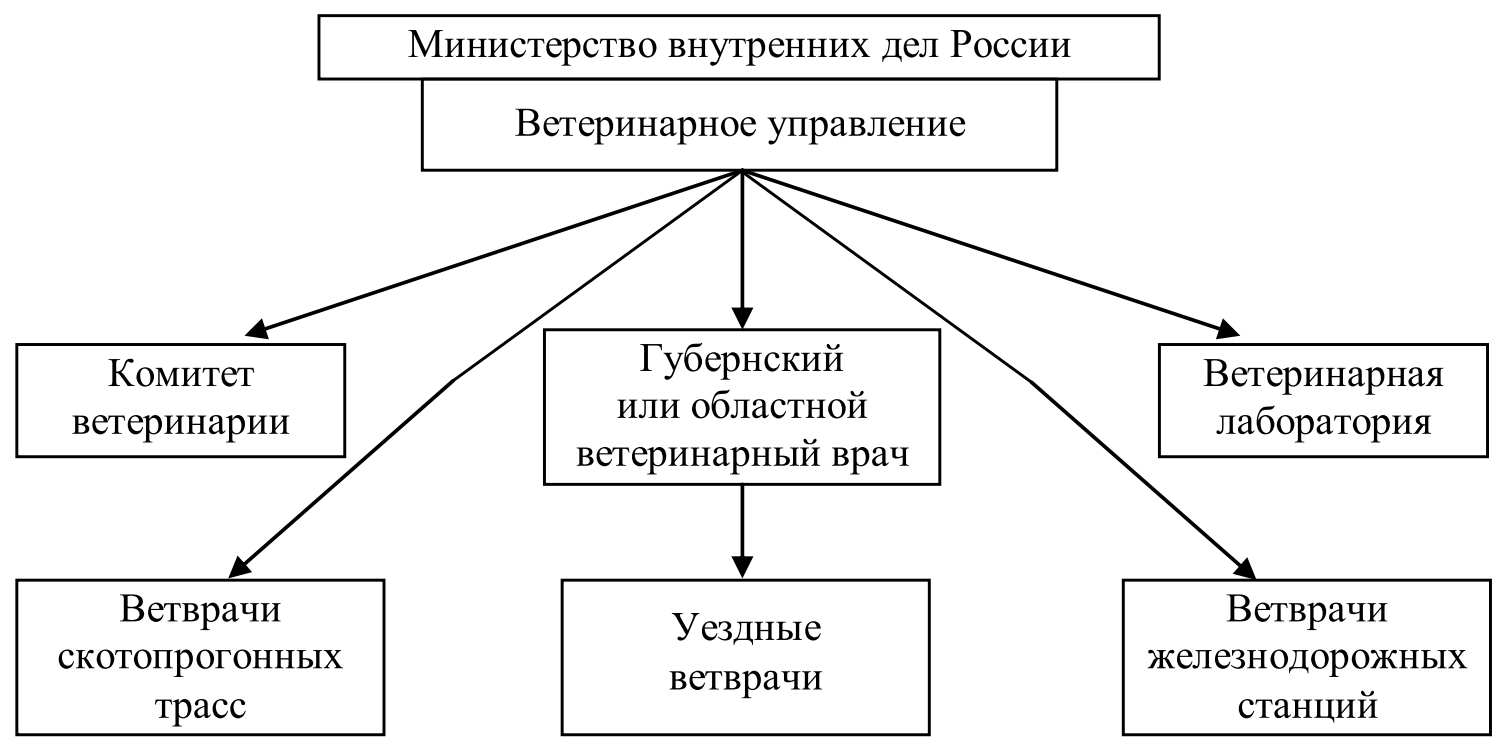

Рисунок 1 - Структура государственной ветеринарной службы России в 1868 г. [3]

В Ярославской губернии до 1890 года было всего 2 земских ветеринарных врача и 10 фельдшеров. Один из врачей на постоянной основе проживал в Ярославском уезде, другой - в Рыбинском уезде. На каждый уезд приходилось по одному ветеринарному фельдшеру.

Как правило, подготовка ветеринарных специалистов осуществлялась в крупных городах Петербург, Казань.

В обязанности ветеринарных специалистов входило:

- клинический осмотр сельскохозяйственных животных; тий;

- организация профилактических мероприя-

- контроль за качеством рациона, содержания животных;

- своевременное лечение сельскохозяйственных животных.
В 1886 году в Ярославской губернии были зарегистрированы: из заразных болезней - сибирская язва, ящур, бешенство, чесотка; из незаразных - кровавая моча, а также ряд спорадических болезней.

В таблице 1 представлена информация по заболеваемости скота по уездам Ярославской губернии в этот период. Наибольшая заболеваемость скота в 1886 году наблюдалась в Ярославском уезде (9,6\% от общего поголовья скота в уезде), при этом падёж скота здесь составил 1,3\% от заболевшего поголовья. Возможно, невысокий процент падежа животных связан с наличием в этом уезде на постоянной основе ветеринарного врача. Наибольшее поголовье скота было сконцентрировано в Ростовском уезде (32,5\%), заболеваемость здесь составила $21,2 \%$ от заболевшего поголовья скота.

Среди заболеваний в рассматриваемый период были наиболее распространены ящур

Таблица 1 - Заболеваемость и падёж скота в Ярославской губернии в 1886 г.

\begin{tabular}{|c|c|c|c|c|c|c|}
\hline \multirow[t]{2}{*}{ Наименование уезда } & \multicolumn{2}{|c|}{$\begin{array}{c}\text { Поголовье скота } \\
\text { на начало года }\end{array}$} & \multicolumn{2}{|c|}{ Заболеваемость скота } & \multicolumn{2}{|c|}{ Падёж скота } \\
\hline & гол. & \% к итогу & гол. & \% к итогу & гол. & \% к итогу \\
\hline Ярославский & 33587 & 24,6 & 3237 & 74,0 & 41 & 27,7 \\
\hline Ростовский & 44382 & 32,5 & 927 & 21,2 & 70 & 47,3 \\
\hline Романово-Борисоглебский & 20126 & 14,7 & 117 & 2,7 & 22 & 14,9 \\
\hline Даниловский & 19207 & 14,1 & 60 & 1,4 & 8 & 5,4 \\
\hline Любимский & 19196 & 14,1 & 31 & 0,7 & 7 & 4,7 \\
\hline Итого & 136498 & 100,0 & 4372 & 100,0 & 148 & 100,0 \\
\hline
\end{tabular}


(74,1\%), сибирская язва (3,3\%), чесотка (2,2\%). Неизлечимыми болезнями являлись сап и бешенство, смертность животных при этих заболеваниях составляла $100 \%$. Относительно незаразных болезней абсолютная смертность наблюдалась от кровавой мочи.

По данным годового отчёта 1886-1907 гг. Ярославской губернии, в 1889 году регистрировались такие болезни повальные и заразные, как дифтерия, сап, бешенство, ящур, чесотка; повальные и незаразные - кровавая моча, мыт, спорадические болезни. При этом абсолютное число заболеваний сельскохозяйственных животных было снижено относительно 1888 года на 8\% случаев.

В 1890 году продолжилось снижение заболеваний заразными болезнями относительно 1889 года (на 2\%), однако инфекционные заболевания отмечались большей злокачественностью.

Так, если в 1886 г. падёж скота составлял 0,1\% от поголовья на начало года, то в 1889 году - 0,6\% (табл. 2).

В 1894 году поголовье скота в Ярославской губернии составляло 612717 голов, в том числе $44,7 \%$ крупный рогатый скот, $28,1 \%$ овцы и козы, $26,4 \%$ лошади и $0,8 \%$ свиньи (рис. 2).

Таблица 2 - Заболеваемость и падёж скота в Ярославской губернии в 1889 г.

\begin{tabular}{|l|c|c|c|c|c|c|}
\hline \multirow{2}{*}{\begin{tabular}{|}
\multirow{2}{*}{ Наименование уезда } \\
\cline { 2 - 8 }
\end{tabular}} & $\begin{array}{c}\text { Поголовье скота на начало } \\
\text { года }\end{array}$ & \multicolumn{2}{c|}{ Заболеваемость скота } & \multicolumn{3}{c|}{ Падёж скота } \\
\cline { 2 - 8 } & гол. & \% к итогу & гол. & \% к итогу & гол. & $\%$ к итогу \\
\hline Ярославский & 42670 & 29,3 & 5486 & 43,4 & 354 & 44,1 \\
\hline Ростовский & 44382 & 30,5 & 6625 & 52,4 & 390 & 48,6 \\
\hline Романово-Борисоглебский & 24481 & 16,8 & 217 & 1,7 & 21 & 2,6 \\
\hline Даниловский & 19207 & 13,2 & 267 & 2,1 & 36 & 4,5 \\
\hline Любимский & 14781 & 10,2 & 42 & 0,4 & 1 & 0,2 \\
\hline Итого & 145521 & 100,0 & 12637 & 100,0 & 802 & 100,0 \\
\hline
\end{tabular}

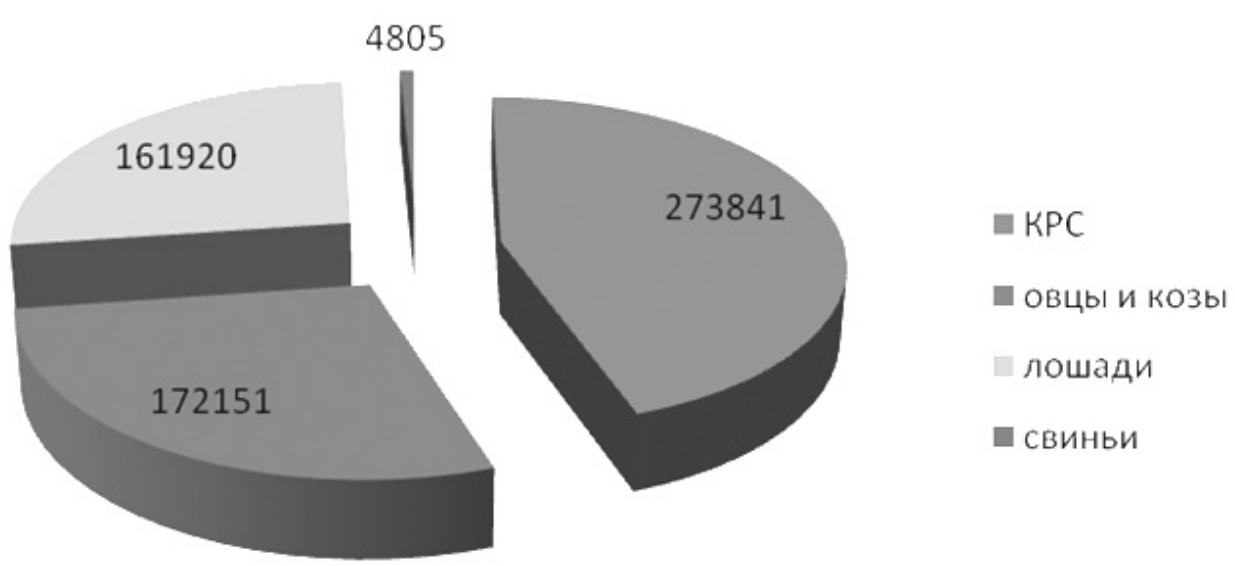

Рисунок 2 - Поголовье скота в Ярославской губернии в 1894 г., гол.

В период 1909-1914 гг. в обязанности ветеринарных специалистов входили предупреждение и прекращение заразных заболеваний, регулярный надзор на конных и скотских ярмарках, базарах [2]. Помимо этого, с 1903 года в Ярославской губернии начинают открываться ветеринарные лаборатории, а с 1906 года - бактериологические кабинеты [1]. В связи с чем наблюдается увеличение количества ветеринарных специалистов (рис. 3).
В этот период наблюдаются изменения и в структуре государственной ветеринарной службы России (рис. 4).

Основными достижениями государственной ветеринарной службы в дореволюционный период стали следующие:

- объединены усилия ветеринарных служб путём проведения всероссийских, губернских, областных съездов ветеринарных врачей 


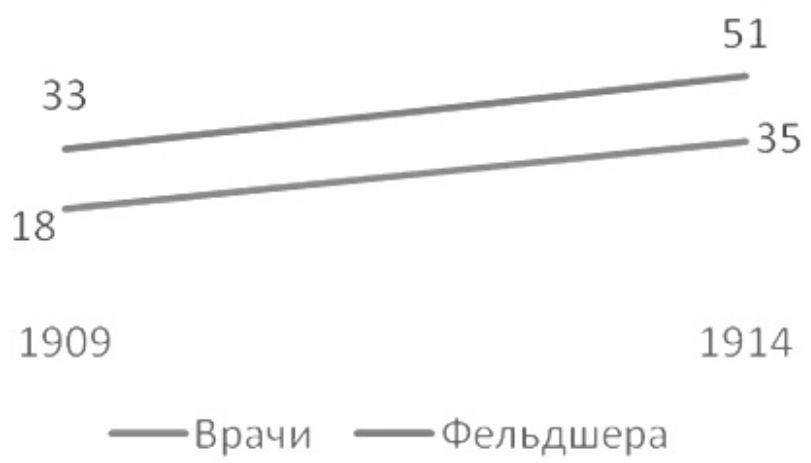

Рисунок 3 - Количество ветеринарных специалистов в 1909-1914 гг., чел.

на борьбу с особо опасными болезнями животных;

- создан ветеринарно-полицейский надзор за промышленным скотом в целях предупреждения распространения заразных болезней животных и обеспечения должного качества продуктов животноводства;

- успешно ликвидирована эпизоотия чумы, повальное воспаление лёгких крупного рогатого скота, сап лошадей в отдельных регионах России.

В послевоенный период ветеринарная служба России, в том числе и Ярославской области активно участвовала в восстановлении разрушенного сельского хозяйства, ликвидировала многие инфекционные и инвазионные болезни, разраба- тывала и внедряла новые эффективные системы ветеринарного обслуживания животноводства.

К достижениям Государственной ветеринарной службы в советский период можно отнести:

- широкомасштабные мероприятия по профилактике инфекционных и инвазионных болезней;

- созданы новые, эффективные структуры научных и практических ветеринарных учреждений;

- успешно защищена территория страны от заноса и распространения заразных болезней животных из зарубежных стран.

Дальнейшее совершенствование государственной ветеринарной службы Российской Феде-

\begin{tabular}{|c|}
\hline Правительственная ветеринария (1433 ветврача $-34,6 \%)$ \\
\hline Ветеринарное управление \\
Министерства внутренних дел России \\
\hline Ветеринарные инспекторы \\
в 90 губернских и областных правлениях \\
\hline
\end{tabular}

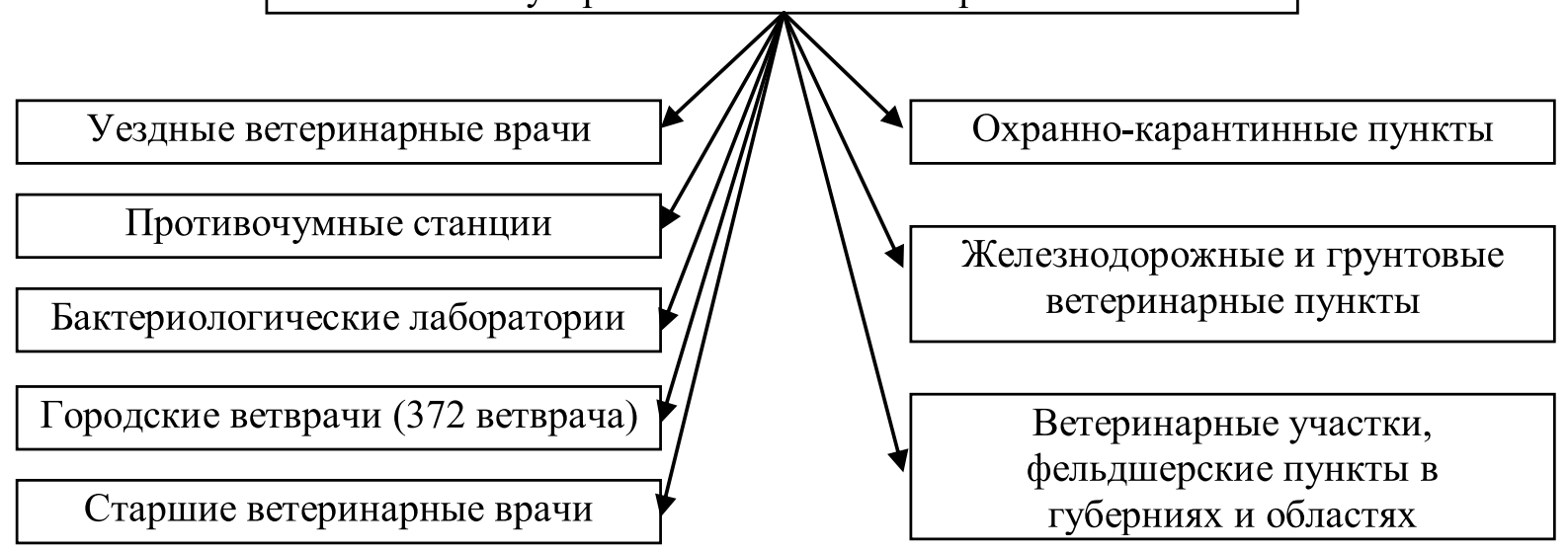

Рисунок 4 - Структура государственной ветеринарной службы России в 1913 г. [3] 
рации охватывает период с 1991-2016 гг. За этот период:

- принят и реализован закон Российской Федерации «О ветеринарии» [4];

- успешно разработаны, приняты и реализованы подзаконные акты по вопросам развития Государственной ветеринарной службы;

- разработаны, приняты и реализованы законы по вопросам ветеринарии в субъектах Российской Федерации;

- органы исполнительной власти субъектов Российской Федерации в области ветеринарии подчинены непосредственно органам государственной власти субъектов РФ;

- широко осуществляются платные ветеринарные услуги государственными ветеринарными учреждениями;

- усовершенствовано бюджетное финансирование учреждений Государственной ветеринар- ной службы путём выделения денежных средств на обеспечение выполнения государственных заданий.

Современная структура государственной ветеринарной службы России представлена на рисунке 5.

В Ярославской области ветеринарная служба с 2012 года стала самостоятельным органом исполнительной власти - департаментом ветеринарии Ярославской области [2].

В настоящее время ветеринарную деятельность в Ярославской области осуществляет областная ветеринарная лаборатория, а также станция по борьбе с болезнями животных.

\section{Выводы}

В дореволюционный период в Ярославской области отмечалась высокая заболеваемость и падёж сельскохозяйственных животных, что

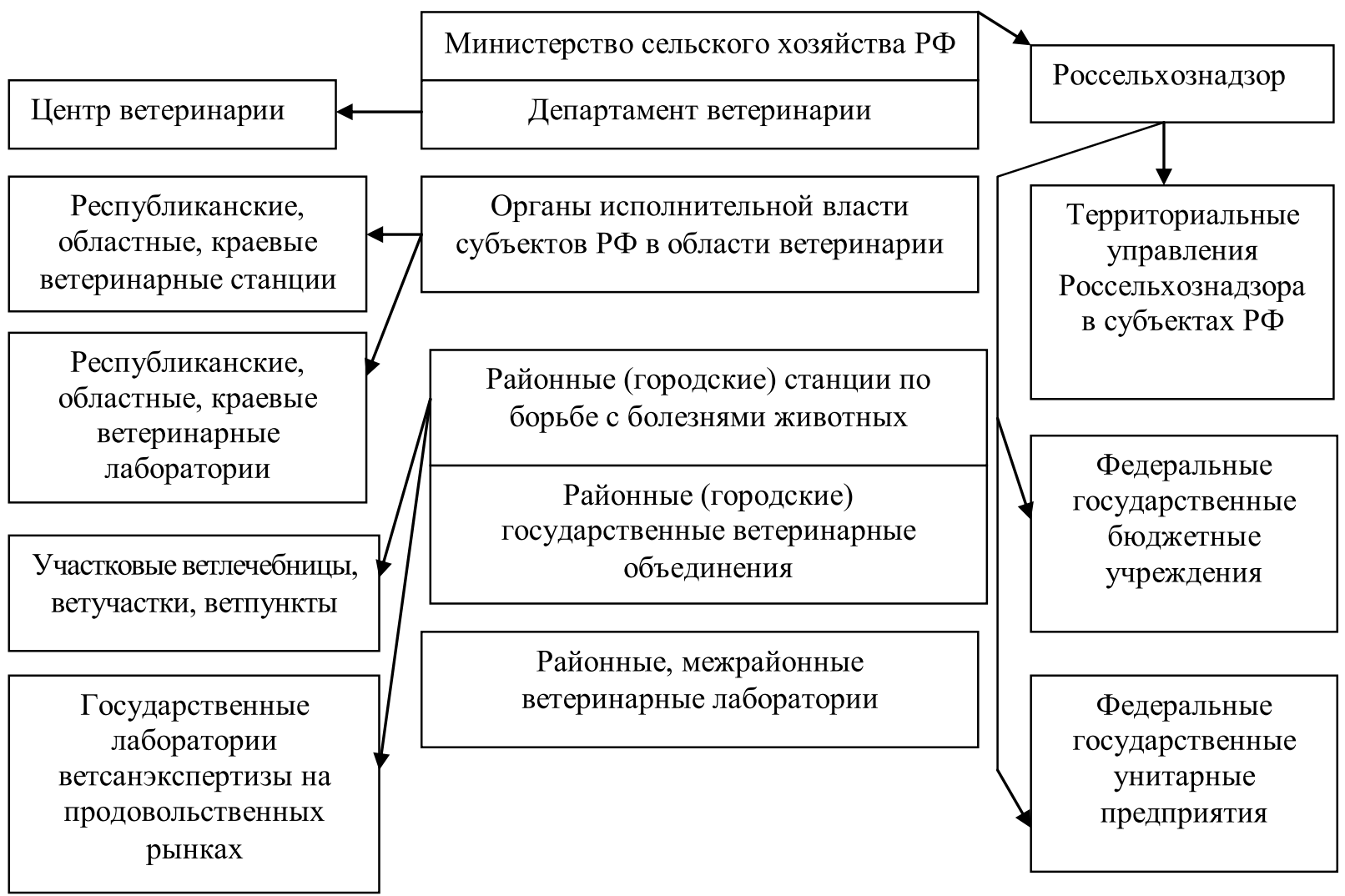

Рисунок 5 - Структура государственной ветеринарной службы России в 2016 г. [3]

было связано с недостаточным количеством ветеринарных специалистов.

В советский период в Ярославской области была сформирована ветеринарная служба, которая успешно занималась профилактикой инфекционных и инвазионных заболеваний.
В настоящее время на основании закона «О ветеринарии в Ярославской области» ветеринарная служба является самостоятельным органом исполнительной власти в лице департамента ветеринарии Ярославской области и обеспечивает продовольственную безопасность региона. 


\section{Лumepamypa}

1. Годовые отчеты Ярославской губернии за 1886-1907 гг. [Текст]. - Ярославль: Типография Губернской Земской Управы, 1907. - 356 с.

2. Развитие ветеринарной службы в Ярославской области [Электронный ресурс]. - Режим доступа: http://www.yarregion.ru/depts/deptvet/Pages/history.aspx.

3. Исторические этапы формирования, развития и совершенствования Государственной ветеринарной службы России [Электронный ресурс]. - Режим доступа: https://cyberleninka.ru/article/n/istoricheskieetapy-formirovaniya-razvitiya-i-sovershenstvovaniya-gosudarstvennoy-veterinarnoy-sluzhby-rossii.

4. Закон РФ от 14 мая 1993 г. № 4979-1 «О ветеринарии» // Ведомости Съезда народных депутатов РФ и Верховного Совета РФ. - 17 июня 1993 г. - № 24. - С. 857.

\section{References}

1. Godovye otchety Jaroslavskoj gubernii za 1886-1907 gg. [Tekst]. - Jaroslavl': Tipografija Gubernskoj Zemskoj Upravy, 1907. - $356 \mathrm{~s}$.

2. Razvitie veterinarnoj sluzhby v Jaroslavskoj oblasti [Jelektronnyj resurs]. - Rezhim dostupa: http://www. yarregion.ru/depts/deptvet/Pages/history.aspx.

3. Istoricheskie jetapy formirovanija, razvitija i sovershenstvovanija Gosudarstvennoj veterinarnoj sluzhby Rossii [Jelektronnyj resurs]. - Rezhim dostupa: https://cyberleninka.ru/article/n/istoricheskie-etapyformirovaniya-razvitiya-i-sovershenstvovaniya-gosudarstvennoy-veterinarnoy-sluzhby-rossii.

4. Zakon RF ot 14 maja 1993 g. № 4979-1 «O veterinarii» // Vedomosti S\#ezda narodnyh deputatov RF i Verhovnogo Soveta RF. - 17 ijunja 1993 g. - № 24. - S. 857.

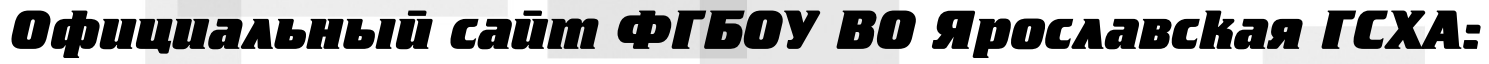 www.yaragrovuz.ru

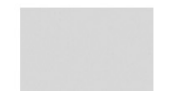

\author{
РУБРИКИ САЙТА:
}

Сведения об образовательной организации -

- Агросоветник - Образование - Абитуриенту -

- Наука и международная деятельность

(в том числе научный журнал «Вестник АПК Верхневолжья») -

- Дополнительное образование - Факультеты

Все выпуски журнала «Вестник АПК Верхневолжья» в полнотекстовом формате, требования к оформлению рукописей, контакты на страничке:

http://yaragrovuz.ru/index.php/nauka-i-mezhdunarodnaya-deyatelnost/zhurnal-vestnik-apk-vekhnevolzhya 